\title{
Persuasive Speech in Propaganda Sponsorship of Prospective Customers Q. Net Infinite
}

\author{
Witra Amelia, Ermanto, Harris Effendi Thahar \\ Universitas Negeri Padang \\ Witraamelia91@gmail.com
}

\begin{abstract}
The purpose of this study was to provide a description of forms of persuasive speech in propaganda sponsorship of prospective customers of Q.Net Infinite Pekanbaru. This research was a qualitative descriptive study which is the object of this research is a form of persuasive speech in sponsor propaganda for prospective customers of Q.Net Infinite Pekanbaru company. Collecting data in this study by observing, recording and recording. The findings of this form of persuasive speech consist of five classifications, namely assertive totaling sixty one data, thirty data directive, five data commissive, six expressive data, and two data declarative. So a form of persuasive speech in sponsor propaganda speech for prospective customers of Q.Net Infinite Pekanbaru which is more often used is a form of assertive speech.
\end{abstract}

Keywords-Speech; Persuasive; Propaganda

\section{INTRODUCTION}

One of the things that everyone who wants to connect with other people needS to know is to take the courage to interact with others. All will not happen without the courage to start. The courage to start greeting others, the courage to talk to others, the courage to respect others, and the courage of others who are self-developed to interact with others. In the case of influencing others, the speaker must be able to understand his or her opponent, by understanding the bent which one is invited to speak, how to character and personality, then the speaker will be able to give the best attitude to his or her opponent. Thus there is no misunderstanding, misunderstanding, is promoting, or helping others, and the most expected is to be able to foster mutually beneficial relationships with others.

When speaking of course someone must pay attention to the concept. Mangatur and Charlina (2006, p.144), describes the concept of speech acts first raised by Austin (1962) in his book How to do things with Tthe word. In the book, Austin itself distinguishes between performative and constative or descriptive speech. This theory was embraced by Searle (1969) after Searle published a book entitled Speech Acts, an Essay in the Philosophy of Language. Furthermore, in this study Austin (in Charlina and Mangatur, 2007, p.23), divides acts of speech into three parts: the act of Lectionary act, illocutionary, and perlocutionary. Thus, the act of speech is the act of speech done by the speaker and the spoken partner in communicating in a context or situation is affected.

Types of speech act There are three types of speech acts including the act of locus, acts of Blokus, perilous action. The form of speech according to Searle (in Rahardi, 2005, p.36), "assertive for example states, reports, shows and mentions, speech directive that asks, begs, demands, advises, and challenges. expressive speeches, expressing gratitude, criticizing and complaining, prompting promises, oaths and threats and declarations of declarations that decide, ban, cancel, allow and forgive".

Furthermore, the act of persuasive speech is a speech delivered by the source (speaker) to the said partner as an effort to influence others to follow the desire or the will of speakers. According toRahardi (2005, p.3), persuasive speech termed the imperative because of the scope of the broader meaning that is based on the function of speech and the involvement of a more complex context.

Shandong (2009, p.150), Explain "Propaganda is a natural imagination and human feeling. Therefore, the activities of the early researchers tried to define propaganda by emphasizing suggestion as the main key, because the propaganda characteristics show the following. "(a) The object is a new thing or idea, which at a certain time has not been received or has not been considered useful, (b) Aims to move a person, a group, or a crowd, on the basis of a persuasive, persuasive, violence, bribery, boycott, terror, and so on; (c) The process of the activity takes place in a suggestive and one direction, in the sense of not expecting any questions or responses; (d) Its nature is suggestive, because its activities strive for the acceptance of a new idea or item, which has not previously been assumed to be true.

Persuasive propaganda tutorial is a speech done by two or more people thus persuasive propaganda speech can be said as a conversation that aims to persuade or invite someone to want to take action or change the attitude in accordance with the desired by the speaker. According to Berno (2011,p. 3) "Q.Net Infinite is a multi-scale international company based in Hongkong has been established since 1998 is a holding company with 18 subsidiaries under it." Q.Net Infinite. This company is a giant company whose scope of the world and its existence has been recognized more than 200 countries and its customers spread across 177 countries. Q.Net Infinite was established by 3 major countries: (a) V-Team: A portion of Asian countries. (B) Scandinavia: Part of European countries. (C) England: British Commonwealth countries. 
Several studies that examine persuasive persuasion used in persuading others in the first previous study (Zaenuri, 2007), findings suggest that the use of persuasive communication in education can support the success of teaching and learning. Secondly (Kasanova, 2016), the findings indicate that). a) technique of rationalization persuasive, trying to invite consumers or viewers with rational things such as content, benefits, and significant results of an advertised product. The rationalization persuasive technique tries to arouse the consumer with the rationality of the young ingredients in the product and the results that will be obtained after the use of the product. Ads with this technique have 10 ad data. b) the Persuasive technique of suggestion, attempting to engage viewers with illogical litigation and in the most efficient advertising duration. Persuasive suggests techniques sometimes take advantage of big holidays or religious holidays to remind viewers of their products. Ads with this technique there are 13 ad data. c) persuasive conformity techniques seek to invite consumers by using the services of advertising stars that have been known and positive image in the community both from the artist, footballers, and officials.

Third (Erviani, 2017), the findings indicate that the research of persuasive communication technique of tourism office of Samarinda city in improving the quality of tourist attraction of Samarinda city, using persuasive communication technique, that is association technique, integration technique, reward technique, arrangement technique, and technique red-herring, is a communication technique used through socialization which is an activity to convey, inform, develop and direct and educate the public about the importance of tourism and tourism awareness. Furthermore (Sari, 2018), the result is a classification of persuasive speech technique in Unstadz Yusuf Mansyur lecture. Based on the findings it is known that persuasive speech techniques used by Ustadz Yusuf Mansyur are, persuasively direct, persuasive indirectly, persuasively using references, persuasively using criteria, persuasively using cause-effect, persuasive use of majors, persuasively using analogy and persuasively using threats. Of the eight persuasive techniques used by the./ ustadz Yusuf Mansyur, persuasive speech techniques using causation are the most commonly used persuasive techniques.

Similarly, research on propaganda speech lies in research (Kadir, 2012), results show that the most commonly used type under the type category is white propaganda by 79 articles, and that the card stack is the most commonly used technique under the category of technique by 107 articles, out of a total of 161 articles. Furthermore (Brunello, 2014), the results show that the propaganda used by means that are not in accordance with the purpose, it must be rejected. Self-determination is a universal driver in human experience. Human life is linked to democracy by this desire. Any propaganda of any kind that succeeds in damaging the area of self-determination is morally and ethically wrong. Working for strength means working for a fantasy. Power alone does not justify the use of propaganda. The audience should not be treated like a mindless creature to be manipulated for short-term purposes of power, or to please paying clients. Commitment to the truth binds four directions from the moral compass to the main moral imperative: the preservation of social contracts and democratic life.

(Prisillia, 2014), findings explain that the unification of North and South Korea in the television drama series The King 2 Hearts through marriage. Marriage in the television drama series became one of the propaganda tools. This propaganda is represented by an agreement between North Korean and South Korean leaders, trust and cooperation, resolution of problems in North and South Korea, and support from the Korean people themselves and the AmericanChinese nation. The North Korean-South Korean Unification in The King 2 Hearts is also influenced by media coverage, particularly television media. While (Susanto, 2014), explained that based on the findings of propaganda tendencies used in the presidential campaign is a type of testimonial. Where each candidate uses many others / other leaders who support the vision and mission of the candidate's campaign. Propaganda is a necessity, because if propaganda is understood as part of a lie. So every second there must be a lie, and the biggest lie is always born from the polity., The type of communicator selected increasingly widespread. This means that communicators are not always people who have the power, position, big name or other. But ordinary or lay people can also be a communicator with an interesting propaganda design, the tendency of issues raised is about personal issues of the candidate.

Furthermore, the same research conducted by (Riyadh TK, 2015), findings show that pragmatically, the language of election political propaganda presented by Barak Obama: (1) Speech statements, statements and suggestions can be used in political propaganda, (2) (3) persuasion, metaphor, repetition, and manipulation are rhetorical devices used in political propaganda and (Hamid, 2017), summarizes the development and experience of the propaganda agency in Malaysia during the era of the Malaysia-Indonesia Confrontation, 1963-1966. Its ambition is to reinforce people's faith in the reigning king and generate hatred against the enemy. As a result, the Malaysian kingdom is continuing with the support of the local peoples and the international political community many. This article mostly uses primary sources such as Akhbar, magazines, royal official documents, reports, and parliamentary Hansards. This article formulates that the propaganda agency plays an important role in dealing with the two largest conflicts before and after independence. the emergency experience becomes a consequence of the efficiency of propaganda strategies when confrontation.

Based on the description that has been presented, the discussion that will be studied in this article is how the form of persuasive speech in propaganda sponsorship against prospective customers company Q.Net Infinite Pekanbaru. 
This study aims to describe, analyze and interpret in detail and systematic form of persuasive speech in propaganda sponsorship of prospective customers company Q. Net Infinite Pekanbaru.

\section{METHODS}

This research was conducted in Pekanbaru, and the process for conducting this research was carried out in stages. The time of this study began on March 11, 2018. This research was included in the form of qualitative descriptive. According to Arikunto (2006, p.10), "Research conducted by explaining or drawing past and present variables (is happening), descriptive research (to describe or reveal)". Qualitative research according to Sugiono (2012, p.15) "Qualitative research is a research method based on postpositivism, used to select on natural objects as a key instrument of sampling of data sources conducted purposively and snowball. The research data was obtained through field observation technique.

Data used persuasive speech in propaganda sponsorship of prospective customers Q.Net Infinite Pekanbaru company when communicating daily. The data source of this paper was persuasive in propaganda sponsorship of prospective customers company Q.Net Infinite Pekanbaru. Indonesian speakers who do a persuasive speech in propaganda sponsorship of prospective customers company Q.Net Infinite Pekanbaru. The data of this paper were analyzed in the following way: the collected data was then transcribed from oral data into the written form. This means that after the data collected and then transferred into the form of writing so it was clear data that has been recorded, then classified form persuasive speech in propaganda, by giving the code number in every propaganda speech.

\section{FINDING AND DISCUSSION}

This study examines the form of sponsorship of persuasive sponsorship of prospective customers of Q.Net Infinite Pekanbaru company. This research describes the form of sponsors persuasive sponsors can be seen in the following exposure.

\section{Assertive Speech Form}

Assertive is a speech act that follows its speakers to the truth of what is said, for example stating, reporting, showing and mentioning.

Speech: (1) "This company will not be closed, if it has clear legality, its government law is legitimate and its religious law exists, so what's in doubt?

Based on the example of the above speech, the speakers explain the legality of the company. Sponsorship encourages prospective customers to be invited to join the company Q.Net. The assertive form of telling is marked by the speaker conveying if the company has a clear legality, the law of the government is legitimate and its religious law exists, so what is beyond doubt ?. The effect of sponsorship so prospective customers will follow the will of sponsors who invite to join the business that has been occupied for several months. In accordance with Searle's theory, it is used that tells about the legality of a clear and legitimate company and its religious law is clear, thus providing a clear proof of what the speaker is saying to be more accurate in receiving information.

Speech: (2) "If you fulfill your obligation to introduce two friends until they buy Q.Net product, then you get a commission. The bottom line in this effort is no element of coercion ".

Based on the example of the above speech, the speaker tells of the obligation to introduce two friends until they buy the product, it will earn a commission. Sponsorship of the sponsor in addition to informing also persuade prospective customers to be invited to join in the company Q.Net Assertive form tells marked by speakers convey if the obligation to introduce two friends until they buy Q.Net products, then you get a commission. The point of this effort is that there is no element of coercion and in accordance with the Searle theory used that tells about the obligation after joining the Q.Net company. So the spiritual propaganda talk sponsorship explains in advance the workings and obligations that must be met in this company. From the explanation, it is clear that a persuasive propaganda speech that gives a statement or stating the true facts.

Speech (3) "Terms to join this company you must have ID card and do not need to use diploma".

Based on the example of the above speech, the speaker informs us about the terms of information to join the Q.Net company. Speakers say you must have a KTP and do not need to use a diploma. Sponsorship encourages prospective customers to be invited to join the Q.Net business. The assertive form of notification is indicated by the speaker conveying the terms of information to join the company Q.Net. It is also found in Sari's research, (2018) which says that there is a form of persuasive speech in Unstadz Yusuf Mansyur's lecture. Persuasive instruction is seen in the form of speech acting classification, as well as only with research done in accordance with pragmatic theory. 


\section{Form of Speech Directive}

A directive is an act of speech that the speaker is doing with the intention that the listener performs the actions mentioned in the utterance (eg, enjoin, plead, demand, advise, challenge).

Speech: (4) "Initially he strongly refused, refused once with this business, because he was anti from the network business. Finally, he was able to follow what I have done, because initially, he was proud of the income as a civil service police officer, I in Q.Net business was my results can exceed his salary as a unit of police pamong praja .

Based on the example of the above speech, the speaker conveyed information that his sister initially refused to be invited to join in this business, because he was anti from the networking business. Finally, he was able to follow what I have done, because initially, he was proud of the income as a civil service police officer, I in Q.Net business was my results can exceed his salary as a unit of police pamong praja". The directive characterized by a commanding phrase. In accordance with the Searle, a theory used that rule belongs to the part of the directive; ie an action intended to cause some effect through the act of ordering. In the speech, the speaker tries to influence the prospective customers with, advice or directions to his or her unaccompanied sister. Speakers influence prospective customers by illustrating that the salary received is greater than his salary as a civil service police unit ".

Speech: (5) "Water Bio Disc can cure various internal and external diseases by therapy, try!"

Based on the example of the above speech, speakers in from on water Bio Disc can cure various internal and external diseases by therapy, try. The directive is characterized by a commanding phrase that is to try. In accordance with the Searle, the theory used that rule belongs to the part of the directive; that is an act of telling. In the speech, speakers try to influence prospective customers to try drinking water Bio Disc, because by drinking this water can cure diseases from within and from outside.

Speech: (6) "Fulfill your duty, that's two people before, nurtured until they also fulfill the obligation".

Based on the example of the above speech, the speaker conveys information about the obligations after joining the company Q.Net. After joining two people who are invited, then nurtured until they also fulfill obligations. The directive is characterized by a commanding phrase that fulfills your obligations. In accordance with the Searle, the theory used that rule belongs to the part of the directive; that is an act of telling. In the speech, the speaker tries to influence prospective customers to fulfill the obligations of two people who fostered the same as they also fulfilled the obligation of getting two people to join the company Q.Net.

\section{Form of Expressive Action}

Expressive, ie speech acts done with the intention for speech to be interpreted as an evaluation of the things mentioned in the utterance (eg praise, say thanks, criticize, complain).

Speech: (7) The third condition is the heir, meaning that there is an heir of this business, which is extraordinary not short term, but long term. Love applause for your heirs. If the father of the mother is dead, but if the father's mother's system has been formed, who receive is your children father, mother.

Based on the example of the above speech, the speaker conveys information about the heirs. The expressive speech is marked by the expression of praise, the speaker persuading the prospective customers about the third condition is the heir, meaning that there is an heir of this business, which is unusually short-term, but long-term. Love applause for your heirs. If the father of the mother is dead, but if the father's mother's system has been formed, who receive is your children father, mother. In accordance with Searle's theory, it is used that praise belongs to the expressive part; namely, in the speech, it appears that the persuasive in the expressive speech that praised about the heirs, praised the advantages of the company Q. Net Infinite.

Speech: (8) "Money is not everything, but everything needs money

Based on the example of the above speech, the speaker conveys information about the function of money. Expressive letters are characterized by a critical expression, speakers persuade prospective customers about the function of money. Everything in this life must need money. Money is not everything, but everything needs money. In accordance with Searle's theory used that criticism belongs to the expressive part; ie in the speech, it appears that it is persuasive in the expressive speech that criticizes the function of money. So in this business, you can earn money if running this business smoothly. 


\section{Form of Comic Action} swear, threaten).

Commissive is a speech act that binds its speaker to execute what is mentioned in his utterance (eg, pledge,

Speech: (9) "You can be conditioned number four, the way you join in Q. Net Infinite, because it can give us added healthy, add strong and get rich".

Based on the example of the above speech, speakers convey information about the condition of healthy people. Commissive commands are characterized by a promised expression. You can be number four by joining this company, because it can make you healthier, add stronger, and get rich. This means that sponsors coax directly if you want to be at number four, you must join. In accordance with the Searle theory used promised included into the commissive.

Speech: (10) "Do not worry, I give a reckless word there must be a solution. The solution will I give later, the most important you understand how it works and get US \$ Dollar ".

Based on the example of the above speech, speakers convey information about the condition of healthy people. Commissive commands are characterized by a promised expression. The speaker will try to give a solution to the father about the capital being discussed, then the speaker tells me later I know, it is important that you understand first how it works and have the courage to join in Q. Net business. In accordance with the Searle theory used promised included into the commissive.

\section{E. Declaration of Declaration}

A declaration is an act of speech the speaker does with the intention of creating new things (status, circumstances, etc.) (such as deciding, canceling, banning, allowing, forgiving).

Speech (11) "Working in Indonesia, we do not have to leave our loved ones behind. Right? ".

Based on the example above, speakers explain inform the existence of companies that work in Indonesia but can earn the US \$ dollars and you do not need to leave the loved ones. When viewed from the propaganda speech that aims to move a person, a group, or a lot. In accordance with the Searle theory used forbidding not to work abroad. Prospective customers can earn US \$ Dollar while still in Indonesia by joining the company Q. Net.

Speech (12) "Have you turned off the cigarette ?, why do I forbid smoking? Because I do not think everyone here smokes.

Based on the example of the above speech, the speaker conveys information to prospective customers not to smoke. Sponsorship of the sponsor is a form of declaration, because the sponsor prohibits prospective customers to not smoke in the room, because the cigarette smoke is very disturbing, for that sponsorship expects cooperation for the smoothness of this event. In accordance with the theory used Searle prohibit pertained in the form of declaration speech.

\section{CONCLUSION}

Based on the results of the discussion, it can be concluded that this form of persuasive speech in propaganda sponsorship of prospective customers of the company Q. Net Infinite Pekanbaru. Persuasive speech consists of five classifications, namely assertive speech totaling sixty-one data, thirty directives, five commissive, six expressive, and two data declarative.

Based on the analysis and conclusions that the authors have done, the authors give advice to readers and language enthusiasts to conduct a more in-depth study of this form of persuasive speech, the authors hope this research can contribute to further researchers and the authors also hope that with this research, should be able to provide knowledge and understanding for readers about persuasive speech, especially in influencing others.

\section{References}

Arikunto, S. (2006). Proses penelitian sesuatu pendekatan praktik. Jakarta: Rineka Cipta.

Brunello, A.R. (2014). "A Moral compass and modern propaganda charting ethical and Political discourse." review of History and political science, 2 (2).

Zaenuri, A. (2007). Teknik komunikasi persuasif dalam pengajaran. Jurnal jalie, 1, (1).

Borneo. (2011). Profil Q.Net, (Online), (http://www.Q.Net. blogspot.com html/,15 Februari 2011).

Chaniago, H. (2012). Bagai mana mempengaruhi orang dan memperolehpeluang. Yogyakarta: Buku Pintar.

Charlina \& Mangatur. (2006). Analisis Wacana. Pekanbaru: Cendikia Insani 
(2007). Pragmatik. Pekanbaru: Cendikia Insani

Shambaugh, D. (2007). China's propaganda system: Institutions, processes and efficacy the china Journal, No 57 Januari 2007.

Effendy, O U. (1992). Dinamika komunikasi. Bandung.: PT.Remaja Rosdakarya.

Josephine, P. (2014). Propaganda unifikasi Korea Utara dan Korea Selatan dalam serial drama televisi Korea The King 2 Hearts .Jurnal E-Komunikasi, Vol 2 nomor 1.

Himawan S. (2014). Propaganda politik calon presiden Republik Indonesia 2014- 2019 (analisis isi berita kampanye pemilihan presiden tahun 2014 pada harian kompas Edisi 4 Juni sampai 5 Juli 2014). Jurnal Humanity, 2 nomor 8.

Nasution, Ahmad Zaini,et al. (1979). Pelajaran tata bahasa Indonesia. Medan:Monora

Erviani, O. (2017). Teknik komunikasi persuasif dinas parawisata kota samarinda dalam meningkatkan kualitas daya tarik wisata kota Samarinda. E-jornal ilmu komunikasi, 5 (3).

Sari, R. Dkk. (2018). Tuturan persuasif dalam ceramah ustad Yusuf Mansur. Jurnal Jom FKIP 5 nomor 1 Januari 2018.

Ria K, (2016). Penggunaan teknik persuasif dalam iklan. Komposisi, 2016, Tahun 1, Nomor 2.

Riyadh. (2015). Studi pragmatik tentang propaganda politik Barak Obama Jornal of Educarion and Practice, 6, nomor 20.

Hamid, S.(2017). Sejarah pembunuhan dan perkembangan agensi propaganda, Jornal of History, 44 nomor 2 , Desember 2017.

Sugiyono. (2012). Metode penelitian pendidikan pendekatan kuantitatif, kualitatif, dan R \& D. Bandung: Alfabeta.

Suhadang, K. (2009). Retorika: strategi teknik dan taktik pidato. Bandung: Nuansa.

Shamsiah, A.K. (2012). A content analysis of propaganda in harkah newspaper, jornal of media and informatio, volume 573 nomor 116. 